\title{
セルフ・モニタリングが学生の職業レディネス、職業観、 職業選択に及ぼす影響
}

\author{
$\bigcirc$ 大嶋玲未 $^{1} \cdot$ 小口孝司 ${ }^{1} \cdot$ 阿部佳奈子 ${ }^{1}$ (非会員) ・ 廣川佳子 ${ }^{1}$ \\ ( ${ }^{1}$ 立教大学大学院 現代心理学研究科) \\ キーワード : セルフ・モニタリング、職業レディネス、職業観
}

\begin{abstract}
The Effects of Self-Monitoring on Occupational Readiness, View of Occupation and Career Selection.
Remi OHSHIMA ${ }^{1}$, Takashi OGUCHI ${ }^{1}$, Kanako ABE $^{1}$, Keiko HIROKAWA $^{1}$

( ${ }^{1}$ College of Contemporary Psychology, Rikkyo Univ.)
\end{abstract}

Key Words : self-monitoring, occupational readiness, view of occupation

\section{目 的}

本研究では、セルフ・モニタリングが学生の職業選択過程 に及ぼす影響を検討することを目的とする。セルフ・モニタ リング(以下、SM と略記) とは、自己を観察し、規制し、コン トロールする傾向性 (Snyder, 1998)であり、さまざまな社会的 場面での個人の行動選択や志向性に差異を生じさせる要因で ある。これまで仕事やキャリアに関わる領域においては、就 業者のSM と、就業行動や業績との関連性に関心が寄せられて きた(e.g. Day et al., 2002)。しかしながら、SMは個人の 就業後の行動や業績ばかりでなく、就業前の職業選択の過程 においても影響を及ぼす要因である可能性が考えられる。

先行研究からは、SM の高い人物は自身を第三者的な視点で 捉えていることや (e.g. Snyder, 1998)、対人的業務への就業 を選択する傾向性が高く(e.g. Day \& Kilduff, 2003)、対人ス キルの求められる職業では業績や評価が高いことが示唆され ている (e.g. Caldwell \& 0` Reilly, 1982; Moser \& Galais, 2007)。SM の高い人物は自身の内面や能力を客観的に捉えた 上で周囲のニーズに合わせた行動を選択する傾向が強いため、 職業選択場面においても高 SM に特徵的な社会的交流能力の 高さを客観的に把握し、そうした能力を活かせる職業として 対人的業務を選択する傾向が高い可能性があるだろう。しか し、これまでSM が自身の能力の活用意識や社会的交流意識と どのように関連し、職業選択に影響を及ぼしているのかを検 討した研究は国内外ともに見当たらない。そこで本研究では、 高校生、大学生を対象に SM と職業レディネスや職業観、およ び職業選択との関連性に注目し、SM が職業選択に及ぼす影響 過程を検討することを目的とする。

\section{方 法}

[調査対象者] 都立私立高校に通う高校生 49 名および都内私 立大学に通う大学生 132 名。年齢は $14 \sim 26$ 歳 ( $M=18.52$ 歳)。 [調查期間］ 2012 年 12 月。

[使用した尺度］セルフ・モニタリング Lennox \& Wolfe (1984)の 13 項目。「感受性」「変容性」の 2 因子。職業レディ ネス 若林・後藤・鹿内 $(1983)$ の 21 項目。「自己知識の客観 化」「職業範囲の限定性」「職業選択の主体性」「職業選択への 関心」の 4 因子。職業観 浦上(1992) の期待価值尺度の 51 項 目のうち 12 項目。「能力活用」「社会的交流」「経済的報酬」

「危険性」の 4 因子。回答は寸べて 5 件法で求めた。志望職 の有無 現時点での志望職種の有無を尋ねた。また、志望職 種ありの場合には具体的な職種の記述を求めた。

\section{SM が職業選択過程に及ぼす影響}

\section{結 果}

SM が職業選択に及ぼす影響を検討するために、共分散構造 分析を行った(Fig. 1)。モデル上の変数は志望業界の有無のみ を観測変数、その他は潜在変数とした。モデルの適合度は GFI
$=.90, \mathrm{AGFI}=.87, \mathrm{CFI}=.96, \mathrm{RMSEA}=.05$ であり、AGFI の值が若干低かったものの、概ね許容できる值を示した。

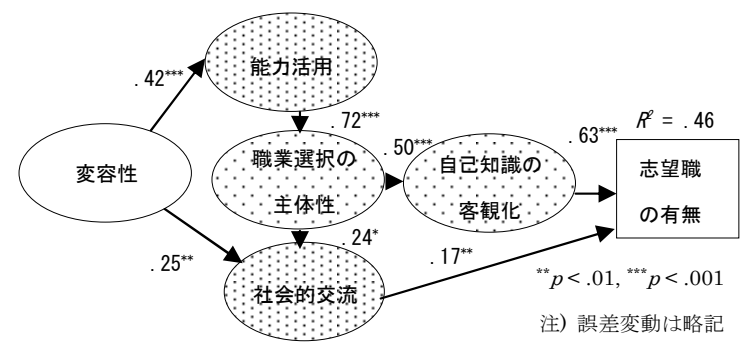

Fig. 1 SM が職業選択過程に及ぼす影響

変容性は能力活用に対する意識、職業選択の主体性を促し、 間接的に自己知識の客観性を高め、志望職の選択を促進して いた。また同時に、社会的交流に対する意識を高めることで、 志望職の選択を促していた。

\section{SM の差異における志望業界の有無}

志望職の有無による学生の SM の差異を検討するために、高 校生、大学生ごとに SM 下位尺度について $t$ 検定を行った。 (Fig. 2)。その結果、大学生において感受性 $(t(130)=2.63, p$ $<.01)$ および変容性 $(t(130)=2.24, p<.05)$ について、志 望職なし群よりも志望職あり群の方が有意に高い得点を示し ていた。高校生は同様の傾向を示していたが、有意ではなか った。また、具体的な志望職種を回答した高 SM 群の内 $71.4 \%$ が日本標準産業分類 (総務省統計局, 2006)における第三次産 業 (対人的業務)に含まれる職種を志望職として回答していた。

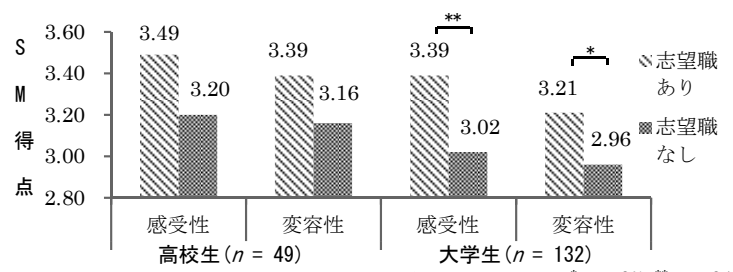

大学生 $(n=132)$
Fig. 2 SM の差異における希望職種の有無 ${ }^{*} p<.05,{ }^{* *} p<.01$

考 察

本研究では、変容性が能力活用意識を高めることにより、 職業選択の主体性や自己知識への客観性を促進し、職業選択 に影響を及ぼすプロセスが示された。同時に、社会的交流に 対する意識が高められることにより職業選択が促されること が示唆された。さらに大学生では高 SM 群において志望職が決 定している傾向性が有意に高く、高 SM で志望職種を回答した 学生の 7 割以上が人と関わる職業を志望していることが示さ れた。 